\title{
Social Conceptions of a Psychiatric Hospital in the Process of Closure
}

\author{
Pedro Machado Ribeiro Neto ${ }^{1}$ \\ Graduate Program in Psychology of the Federal University of Espirito Santo, \\ Vitória, ES, Brazil \\ Luziane Zacché Avellar \\ Graduate Program in Psychology, Department of Social Psychology and Development \\ of the Federal University of Espírito Santo, Vitória, ES, Brazil
}

\begin{abstract}
The study aims to understand the social conceptions of a psychiatric hospital in closing process. Participants live in a residential neighborhood near to the hospital, where three therapeutic residences (TRs) are located, whose residents are egress of the hospital. Through ethnographic perspective, 22 interviews were realized, addressing the evocations about the psychiatric hospital, its closure and the destiny of the egress. The psychiatric hospital was conceived as a reference to the inhabitants, being represented as a halfway house and conceived as a necessary place. The participants showed displeasure with the closure, but at the same time, a favorable position to its deactivation, based on interaction with the former inmates of the hospital that lives in the neighborhood, represented as non-aggressive. Participants suggested that TRs are transferred to remote locations. The representations observed indicate the need of keep the psychiatric hospital open or the creation of other similar spaces, providing the social withdrawal of the egresses. Thus, it is necessary to discuss the possibility for coexistence between supposedly different groups, since the tendency to removal, as observed in this study, can be as a process necessary for the defense of group identity, but must be fought.
\end{abstract}

Keywords: Therapeutic residences, deinstitutionalisation, psychiatric hospitals, social representations, ethnography.

\section{Concepções Sociais sobre um Hospital Psiquiátrico em Processo de Fechamento}

\section{Resumo}

O estudo objetiva conhecer as concepções sociais sobre um hospital psiquiátrico em processo de fechamento. Os participantes são habitantes de um conjunto residencial vizinho ao hospital psiquiátrico, onde se localizam três residências terapêuticas (RTs), cujos moradores são ex-internos do hospital. Por meio de perspectiva etnográfica, foram realizadas 22 entrevistas no espaço público do conjunto residencial, abordando as evocações sobre o hospital psiquiátrico, seu fechamento e o destino dos ex-internos. $\mathrm{O}$ hospital psiquiátrico se constituiu como uma referência para os participantes, representado como uma

Mailing address: Av. Fernando Ferrari, ${ }^{\circ}$ 514, Campus Universitário de Goiabeiras, Universidade Federal do Espírito Santo, Prédio Lídio de Souza, Vitória, ES, Brazil 29075-910. Phone: (27) 9 9272-0269. E-mail: mrn. pedro@gmail.com and luzianeavellar@yahoo.com.br

This study was funded by a doctoral scholarship awarded by the Brazilian Federal Agency for the Support and Evaluation of Graduate Education (Coordination for the Improvement of Higher Education Personnel CAPES). 
casa de recuperação e concebido como lugar necessário. Os participantes demonstraram descontentamento com o fechamento, mas apresentaram uma postura favorável à sua desativação, fundamentada na convivência com moradores das RTs concebidos como não agressivos. Contudo, os participantes sugerem que as RTs sejam transferidas para locais afastados. Os resultados apontam a necessidade de manter os hospitais abertos ou a criação de outros espaços semelhantes, proporcionando o afastamento social dos moradores das RTs. É preciso discutir as possibilidades para a convivência com ex-internos de hospitais psiquiátricos, no sentido de possibilitar a coexistência entre grupos supostamente diferentes, pois a tendência ao afastamento, como observada, se constitui como um processo necessário para defesa da identidade grupal, mas deve ser combatida.

Palavras-chave: Residências terapêuticas, desinstitucionalização, hospitais psiquiátricos, representações sociais, etnografia.

\section{Concepciones Sociales sobre un Hospital Psiquiátrico en Proceso de Cierre}

\section{Resumen}

El estudio tiene como objetivo comprender las concepciones sociales acerca de un hospital psiquiátrico en proceso de cierre. Los participantes viven en un barrio próximo al hospital, donde se encuentran tres residencias terapéuticas (RTs), cuyos residentes son ex pacientes del hospital. A través de la perspectiva etnográfica, se realizaron 22 entrevistas, cuya guía de la entrevista se dirigió a las evocaciones sobre el hospital psiquiátrico, su cierre y el destino de los ex pacientes. El hospital psiquiátrico fue concebido como una referencia, representado como una casa de recuperación y un lugar necesario. Los participantes mostraron descontento con el cierre, pero al mismo tiempo, una posición favorable para su desactivación, basada en la interacción con los moradores de las RTs, representado como no agresivo. Los participantes sugirieron que RTs son trasladadas a lugares remotos. Las representaciones observadas indican la necesidad de mantener el hospital psiquiátrico abierto o la creación de otros espacios similares, proporcionando el aislamiento social de los egresos. Por eso, es necesario discutir la posibilidad de convivencia con los ex internos de hospitales psiquiátricos, ya que la tendencia a la exclusión puede ser un proceso necesario para la defensa de la identidad de grupo, sino que debe ser combatido.

Palabras clave: Residencias terapéuticas, desinstitucionalización, hospitales psiquiátricos, representaciones sociales, etnografía.

Mental health policies based on the deinstitutionalisation of mental illness favour the closure of psychiatric hospitals. Therefore, mental health patients who were institutionally confined have begun to cohabit social spaces. Individuals discharged from long psychiatric hospitalisations who do not have social support and family ties are transferred to Therapeutic Residences (TRs). According to Decree 106/ Ministry of Health, TRs should be integrated into local communities (2000). However, it is necessary to determine how the residents of the places where the inmates will be transferred feel about the former patients' presence and the clo- sure of the psychiatric hospital. Are they aware of the inclusion of this population in their neighbourhood?

The present study discusses the perspectives of residents of a housing complex in which three TRs are located. This complex is near a psychiatric hospital that was recently closed and whose inmates were transferred to these TRs. This study uses the theoretical framework of social representations. Social representations are a form of social thought, shared knowledge that is constructed and transmitted in daily relationships and across generations and has a practical purpose. Analysis of social representations 
provides insight into social behaviours (Jodelet, 2005; Jovchelovitch, 2004).

Understanding the social representations of the psychiatric hospital problematises the relationship established with the discharged inmates. In addition to the theoretical framework of social representations, the present study is based on evidence from the Italian experience of deinstitutionalisation, which is considered essential for changes in mental health care. Deinstitutionalising involves problematising the legislative, administrative, and scientific apparatuses that support the existence of the psychiatric hospital, which were based on beliefs about the danger of "mental disorder" (Basaglia, 1982; Rotelli, Leonardis, \& Mauri, 2001).

In Brazil, social resistance to the idea of closing psychiatric hospitals and establishing community mental health services has been observed and is an obstacle to such policies in this region (Ministry of Health, 2011). Moreover, there is a stigma attached to individuals discharged from long psychiatric hospitalisations:

The fact of being linked to a psychiatric institution is indeed a determining factor because it implies a prisoner status and the removal of certain rights. In fact, the detention status rather than the patient status is what originates a whole series of undervalued or negative attributions. (Jodelet, 2005, p. 133)

\section{Objectives}

The present study aimed to identify housing complex residents' conceptions of a psychiatric hospital and, more specifically, their conceptions of its closure and the destination of the discharged inmates who have no social support and family ties.

\section{Methodological Approach}

The field study was performed in the public areas of the housing complex using an ethnographic approach: "the street ethnography technique consists in exploring urban areas that will be investigated through walks "with no particular destination' in their territories"
(Rocha \& Eckert, 2003, p. 4). Urban ethnography involves describing the practices and knowledge of individuals and groups through observation and conversations and requires the investigator to be in the field - a street, an avenue or a neighbourhood - frequently. Through interviews and systematic observation of the scenarios and characters involved, the investigator discovers the meanings resulting from that routine (Rocha \& Eckert, 2003).

The field study was conducted by the first author and was performed during 6 trips to the field. The trips occurred between October 2011 and February 2012 on different days and at different times, and each trip to the field lasted between two and four-and-a-half hours. Insertion in the study field was facilitated by the investigator's previous experience conducting a study in the psychiatric hospital and in the housing complex during the author's undergraduate and master's degrees programs, respectively.

The housing complex where the field study was conducted is primarily composed of residential houses and several shops. Prominent among these shops was a bakery that was visited not only by the residents of the housing complex but also by the residents of the TRs; one of the TRs is located on the second floor of this bakery. The bakery is located on the main street that leads to the housing complex and is in front of a small park, which facilitated the process of conducting interviews in that neighbourhood.

A total of 22 interviews were conducted. They were recorded with audio equipment and fully transcribed. The interviews were conducted in the main and side streets of the housing complex near the participants' homes and in the shops. Participants were randomly selected as the investigator walked through the neighbourhood. Occasionally, two or more people were interviewed at a time.

The name of the psychiatric hospital that had recently closed was Adauto Botelho Hospital, and the interview script consisted of topics that included the evocations of the word "Adauto", attitudes toward its closure and perceptions of the future destination of the inmates who did not have family. The investigator acquired 
additional data due to his presence in the field, including participation in a barbecue and in a religious gathering. The investigator was invited to these social events by the study participants, which indicated the neighbourhood's inclusive daily practices.

The transcribed material was analysed using Thematic Content Analysis, as proposed by Minayo (2004). First, all of the interviews were carefully read. Next, themes were identified and then organised into categories that were used as a basis for organising the results. Finally, the field diary records were read and analysed.

In accordance with Resolution 466, which regulates research with human beings (Ministry of Health, 2012), all of the participants agreed to participate in the study and were informed that they could stop the interview at any time. They were also assured that their identity would remain anonymous and were informed that the information they provided in the interviews could be presented at events and published in scientific journals.

\section{Results}

\section{Evocations and Associations Regarding the Psychiatric Hospital}

The evocations suggested three main themes: the first encompasses definitions of the psychiatric hospital; the second consists of evocations that suggest a positive assessment of the hospital; and the third consists of negative assessments of the hospital. The social representations of the hospital closure and the fate of the inmates are presented after the explanation of the three main themes.

In the statements categorised in the first main theme, the words "crazy" and "recovery" were mentioned often: "they say that crazy people stay there, but everyone has a chance to recover, right"; "Adauto is a recovery place that try to recovers some individuals who act differently than what society considers acceptable". One participant defined the psychiatric hospital as a "house of crazy people" and demonstrated difficulty identifying other invocations: "This is the only thing I would say about it. I was born and raised here, and during my entire life... I learned that it was the house of crazy people; mentally unbalanced persons live in there". Moreover, according to another participant, "up there is the place that accommodated the crazy people who hit others; I had a friend who worked there... in that place, people hit and assaulted others". One participant talked about the historical aspects of the psychiatric hospital and the characteristics of the population treated there:

In the past, Adauto was treated like those patients... poor... lazy, the psychiatric patients themselves, they were known as crazy, right?! Actually they were not known as crazy, but rather as individuals who were possessed by a devil, something bad. So I think that Adauto is known as... it is used by drug users as well; then, what does Adauto have? It has drug users, addicted people, and psychiatric patients who really have a problem in their heads.

Notably, the main themes were configured to facilitate data visualisation. However, two and sometimes three main themes could be observed in a single sentence. This specifically occurred when participants expressed the idea that the psychiatric hospital was a lunatic asylum and hell while also saying that it was a house of protection and recovery: "Well, everybody says that it is hell, but I do not agree with it. I think that it is a recovery house. A place that recovers the elderly who are there with depression and crisis, right". Similarly, another participant reported:

The first thing that comes to mind is lunatic asylum, a place for people who have a disorder, a mental disorder, but to define it in five words I would say... it is treatment, psychiatry, psychological support, care, and strong social work as well.

In the statements associated with the second main theme, which comprised positive assessments of the psychiatric hospital, the expression "problem" was frequent. These statements designated the psychiatric hospital as a solution for certain problems:

When you provide treatment for these people with mental disorders, you avoid other 
problems, family problems, or even real problems... problems associated with the streets because very often, the family abandons these people on the street, which results in bigger problems, a problem for the society.

There are several families that sometimes have a problem at home and then want to get rid of the problem, or sometimes they cannot stand or cannot deal with those problematic people at home, and then prefer to admit them to the hospital. So I would say that there is commitment, dedication, and love from the professionals to people with disabilities.

The somewhat positive assessment of the psychiatric hospital was also observed with regard to the issue of drug addiction: " $a$ place that people need. Some of them have psychiatric problems, others have problems with drugs, involvement with drugs, then there are several types of diseases that are treated there that I think is important". The psychiatric hospital was also an option for people who had been abandoned: "people who were abandoned in their own houses and had the option to be taken to the hospital". In this regard, a close relationship between the hospital and the housing complex was observed:

The Adauto Botelho Hospital is a reference for us here... it is a reference for our neighbourhood. Everyone that calls says, "I want to be close to Adauto". People take a bus, they do not know and then use the Adauto Botelho as a reference. They say: "I live close to Adauto Botelho".

When describing this relationship of closeness and familiarity between the housing complex and the psychiatric hospital, it is notable that some participants reported having relatives who worked at the hospital. Moreover, one participant worked at the institution, and others had visited the hospital, but for other reasons.

However, the third main theme consisted of negative or unfavourable assessments of the psychiatric hospital, but these appeared less frequently than statements associated with the previous theme. One participant reported that the psychiatric hospital once practiced "shock treatment" and had "beat several patients". One participant described a visit to this institution:

We see that it is a sad thing, the hospital used to admit even children. I was very young and could not understand what this thing of people with head problems was. Then, I asked the nurse why those children were there, trapped like a prisoner behind a grid. Then, the nurse told me that those children had the same problem in their heads like the others.

In a similar negative assessment of the psychiatric hospital, one participant discussed the drug treatments that the patients were subjected to:

I am sure that they give too much medicine to the patients, and I think medicines cause further effects on them. They are there to be recovered, but I believe that the treatment with all these medicines make them worse. They are there to be recovered, but... in my opinion, they do not recover very well because of the medicines that are given to them.

\section{The Closure of the Psychiatric Hospital}

The participants know about the closure of the psychiatric hospital, and many of them had questions about it: "Are the people leaving the hospital recovered?"; "Where are the aggressive individuals going?"; "Are we going to have another hospital to replace it?"; "What about the poor people who depend on the hospital to obtain medicine... physiotherapy... psychologist?" In addition, the terms "need" and "depend" were repeatedly used to explain that some people need the institution to continue operating: "But I did not want to see it closed because many people depend on that hospital, they need it'. In discussing the closing, one participant commented,

Oh, I think it is wrong! I think they have to build more clinics to hospitalise these types of people and should not close the ones that are available. It is about the patients'... improvement, so they can have... better comfort up there. There are several properties around, so Adauto could build a house so the patients will have leisure activities, they 
do not have leisure activities here in the housing complex.

The participants also defended the need to continue operating the psychiatric hospital because cases of aggressive behaviour required intervention. Therefore, the emergence of differences between what were considered two distinct groups should be noted: "There is an Adauto for those people who are presenting advanced stages of the disorder, dangerous individuals, and that is okay. There are many people there who have nerve problems and need more affection rather than a hospital". Several statements illustrating this difference between the groups are presented below:

The first treatment should be there! Can you imagine, if I take a crazy individual who beats or gets other people's things, and put him/herin a gymnasium, in a neighbourhood with a lot of people? The ones from here, we can see that they are not aggressive, not yet. But there are some crazy individuals who are aggressive in their first stage. The person with mental illness is dangerous, they are extremely strong... I've seen a woman going crazy in a church! Nobody could handle her! They needed a rope to loop her like an animal! Separation is necessary because where will this be done? If there are still individuals who behave like that, right.

However, one participant emphasised the need for the psychiatric hospital to remain in operation for people with "psychological disorders", differentiating the inmates that were not dangerous from the inmates of a criminal lunatic asylum, who would be dangerous:

Adauto is confused with a lunatic asylum, and this is not true. The state has its own judiciary lunatic asylum, which is in Cariacica Sede and treats these people who are socially dangerous, involved in crime, but have mental disorders. In contrast, the Adauto Botelho deals more often with people who are more docile, people who have psychological disorders but do not represent a notable danger to other people, to society in general.
However, some participants had a positive attitude about the closure of the psychiatric hospital because of their actual experiences with the TR residents in the housing complex: "Based on the people that I see here in the housing complex during a general interaction, I think they would not need to be treated and confined in a clinic". According to another participant:

. . . nothing has changed for me since they moved here, it remains the same, nothing happened, or even improved, and there are some people who are worse than them. They do not speak evil of anyone, they are quiet and live in their own world... I did not see any difference.

\section{The Future of the Hospital Inmates without Family Ties}

In response to this question, the participants expressed strong emotions about the presence of TRs in their neighbourhood, reporting their approximate number. The word "here" was often mentioned: "They come to the housing complex, and there are three of them here now! There were four". In addition, one participant reported, "Right here is an example of where these people are being accommodated. They rent the house, there are about five houses here that are specifically to accommodate these people who are being treated at the Adauto Botelho".

When the participants discussed what would happen to the hospital inmates who did not have family ties after the closure of the institution, especially considering that many of them lived in their own neighbourhood, they suggested the creation of a place bigger than the TRs to house this population, believing that such a place would then benefit the TR residents:

A house with a backyard, so they could walk and not be trapped like they are here. If you walk through the park, you see them walking around the entire day. In my opinion, they are doing wrong, they should find a place with a backyard so they could sunbathe, they do not sunbathe there.

Similarly, another participant approved of building a larger place outside of the housing complex boundaries, picturing an area with a 
"garden and a recreational area for them". Another participant went further and outlined an ideal place dedicated to that population, which the participant called a "ranch-house":

. . I I even suggest that, for example, the houses that the State uses here to re-socialise them, build these houses in larger areas, where the inmates would have the option of doing therapy while working . . . That they had something to do, it is... a ranch-house! They would have that therapy of planting, harvesting, picking, and selling the fruit, I think so, using plantation areas.

\section{Discussion}

\section{Conceptions of the Psychiatric Hospital}

In the current study, the theoretical framework of social representations was used to analyse a group of residents' conceptions of a psychiatric hospital. According to Jovchelovitch (2004), social representations are associated with the psychosocial, cultural and historical contexts of their origins, illustrating the essential relationship between forms of knowledge and the context of their elaboration. Jovchelovitch (2004) uses the concept of "cognitive polyphasia" to discuss differences in representation. Cognitive polyphasia refers to the variability of the knowledge present in the representational forms, which allows an individual or a group to present contradictory discourses about a subject according to the interests and roles that the elaborated representations fulfil: "The dynamic of the representational form allows variation and the ability to contain as many rationales as needed for the endless variety of sociocultural situations that characterise the human experience" (p. 27).

Social representations allow individuals to process information from everyday reality and develop ways to address social situations. For example, individuals can develop defensive strategies against a threat to control or remove this insecurity. Furthermore, these strategies allow the positively evaluated group identity of a reference group to be maintained: "At the level of group affiliation in everyday relationships, individuals have representations about their own reality, which may guide possible behaviours in their interactions with other groups and guide social identification/differentiations" (Bonomo, 2010 , p. 72). Thus, the social representations elaborated by the participants of the current study guide their social behaviours. For example, social representations inform residents' attempt to cope with a situation of conflict (the closure of the psychiatric hospital) and preserve and create a positively evaluated group identity.

The literature on Italian deinstitutionalisation emphasises that psychiatric hospitals are generally spaces in which human rights violations occur (Basaglia, 1982; Rotelli et al., 2001). Unlike the statements of the Italian authors and the Brazilian legislation regarding deinstitutionalisation policies, the statements of the participants demonstrated a positive representation of the psychiatric hospital (Ministry of Health, 2000, 2011).

In agreement with the results of the present study, Maciel, Barros, Camino, and Melo (2011) indicate that several studies have reported positive views about psychiatric hospitals, especially among the families of the inmates:

These studies showed positive representations of the psychiatric hospital, based on the fact that the hospital treats and takes care of the mentally ill and also that the presence of the patients at home generates tension and fear in family members, legitimising hospitalisation. (p. 201)

These statements indicate the need for further problematisation of the psychiatric hospital and the representations it evokes because such hospitals are failed institutions and should be abolished due to the violence and the human rights violations that occur in these establishments (Basaglia, 1982). This view, however, is different from that taken by the participants of this study.

The housing complex analysed in the present study was founded approximately two decades after the psychiatric hospital opened and developed around it. Because they are neighbours, they have a shared history: "Adauto Botelho Hospital is a reference for us here". 
Thus, during almost sixty years of existence, the hospital has been part of the life scenery of the neighbourhood and is a recognisable part of the landscape. This creates a feeling of familiarity with the hospital and therefore an appreciation of it. Appreciation for the place of origin was discussed by Rivas and Inostroza (2003) in a study about regional identity. A study conducted in an economically disadvantaged Chilean region revealed that the participants praised the natural resources of the place of origin, especially the beauty of the landscape where they lived, despite the series of adverse conditions present in the life of that population, which were deemphasised: "Our participants have highlighted the importance of regional characteristics with a positive assessment and have overshadowed those with a negative connotation" (p. 90).

Therefore, regional identity is associated with individuals' place of origin. This discussion about regional identity is applicable to the present study, as is apparent in the participants' need to view the psychiatric hospital positively, showing a close relationship between themselves and the psychiatric institution, as noted by Moreira (2007): "there are a large number of surrounding residents whose lives are or were intertwined in some way with the hospital" (p. 92). The psychiatric hospital is located in the participants' neighbourhood and therefore is part of the natural scenery of that place; it has been cognitively transformed into part of the landscape. Understanding the hospital as a component of the physical, cultural and historical environment of the participants and as an integral part of the place of origin suggests that residents' appreciation of it is essential to "... preserve the environment in which their own identities are rooted" (Jodelet, 2005, p. 353).

The participants viewed the psychiatric hospital as a recovery home for crazy individuals. In contrast, Leonardis, Mauri and Rotelli (2001) argue, "... the lunatic asylum is not a home: individuals go or are in the lunatic asylum for lack of alternative homes, money, support, resources to live and to be recognised in the dynamic of social exchanges" (p. 72). For this reason, Italian reformers began to declare psychiatric hospitals as uninhabitable places, closing them and providing care in other places in the city. Despite this statement of lunatic asylums as uninhabitable places, the participants of the current study represented the psychiatric hospital as a home and also as a solution to various problems, including family, social, mental or drug problems. The hospital was therefore a solution to "something bad" which reflects the need for further discussion about the institution, which would promote the development of a shared understanding about the importance of its closure. Thus, the psychiatric hospital was believed to offer relief from conflict situations, preventing disruption in various spheres of life and assuming a positive character in the opinion of the participants as a protection against "bigger problems, a problem for the society".

Despite their appreciation of the psychiatric institution, several of the participants mentioned negative aspects, such as its precariousness, the presence of physical violence and the excessive medications given to the inmates. Lima (2005) recalls the history of this psychiatric hospital and indicates that, once admitted, the inmates were immediately medicated to prevent disruptions and to prevent possible crises. Therefore, the psychiatric care provided "... was characterised by traditional actions, represented by a therapy almost exclusively based on medication, in addition with the use of electroshock and 'crisis stabilisation units' or 'cubicles' for more 'agitated' inmates" (Lima, 2005, p. 83).

Despite statements asserting that medication was an important way to control the hospital inmates, a study conducted by Jodelet (2005) revealed that the medication was considered negative by the families that hosted former inmates in their homes because it was a hindrance to the inmates' ability to enter the workforce. In addition, the medication associated the inmates with the image of "mentally ill inmates" who were capable of evil and therefore avoided by the families. Even in different contexts, the medicalisation of the former inmates of the psychiatric hospital was negatively represented by the participants and seen as a factor preventing their recovery: "all these medicines make them worse". 


\section{Conceptions of the Closure of the Psychiatric Hospital}

In contrast to those who advocate for deinstitutionalisation (Basaglia, 1982; Ministry of Health, 2000, 2011; Rotelli et al., 2001), the present study showed that the participants were disappointed with the closure of the psychiatric hospital: "But I did not want to see it closed". One participant expressed her disappointment by commenting on the arrival of former inmates to the neighbourhood due to the hospital closure and suggested, "there are several properties around, so Adauto could build a house". In their responses, the participants referred to the inmates as they discussed the hospital closure, questioning whether they were recovered, primarily because some of the inmates were supposed to be aggressive. These participants demonstrated discomfort with the hospital closure and revealed that the representations of the psychiatric hospital are based in part on the idea that the inmates are aggressive. Similarly, Pacheco, Almeida and Rodrigues (2007) conducted an ethnographic study of psychiatric reform in Campinas and noted a resistance to changes in psychiatric hospitals in terms of community services. This resistance was based on the idea of a social threat: "Several individuals believe that the lunatic asylums will be closed and the crazy individuals will be loose on the streets without treatment and threatening the population and the social order" (p. 125).

Two different groups were conceptualised within the participants' statements: "aggressive" inmates and "non-aggressive" inmates. Nonaggressive inmates were recovered and would need "more affection rather than a hospital". Therefore, the representation of two distinct forms of insanity was observed: one form was somewhat more tolerable and included recovered individuals who could be living in the housing complex; the other form of insanity was considered dangerous, and the individuals suffering from it should be separated by being confined in the psychiatric hospital. Accordingly, the dangerousness attributed to certain forms of insanity perpetuates the idea that the psychiatric hospital needs to continue operating.
However, the representation of insanity as a dichotomy between aggressive and nonaggressive individuals, especially the affirmation that "the ones from here are not dangerous", seems to facilitate the residents' social acceptance of the inmates who have experienced long hospital stays. For Jodelet (2005), the danger associated with inmates is a central theme in discussions about the social destination of insane individuals. In her study, Jodelet observed the formation of two poles represented by the difference between "retarded individuals" who were similar to children and whose coexistence was tolerated and "nervous individuals" who were not submissive, unable to work, and could undermine the safety of people around them, making their stay on the premises undesirable. This representation was used by the families to evaluate the possibility of the patients' permanent residence on their property: "From this point of view, two types of patients are quickly judged: in a positive way, the retarded, and in a negative way, the very nervous individual" (p. 209).

Similarly, the data from the present study showed that the inmates from the psychiatric hospital are positively represented and in some ways accepted. However, this attitude develops the moment they become members of the same group as the participants, that is, when they begin to live in their neighbourhood: "The ones from here, we can see that they are not aggressive, but there are some insane people who are dangerous". Therefore, the aggression status is removed from the former inmate and is transferred to a symbolic image of "insane people who are dangerous". In addition, one participant reported seeing a woman behaving manically in church and being "extremely strong" - so strong that they had to "loop her like an animal". For such cases, which were either represented by the idea of the dangerous insane individual or the actual experience of a women in the church, a psychiatric hospital would be necessary as a "first treatment" because "there are still individuals who behave like that".

One of the participants established a difference between the inmates from this 
psychiatric hospital and the inmates from a judicial lunatic asylum, which accommodates the "people who are socially dangerous" (i.e., individuals who are "involved in crime, but have mental disorders"). Thus, the participant shifted the sign of dangerousness associated with the hospital's inmates to more distant frontiers - the criminal individuals are "in Cariacica Sede". This production of otherness through the allocation of the sign of dangerousness to distant groups can be interpreted as group favouritism, placing the negative trait on another group. In addition, a minority of participants reported that they did not have a problem with the closure of the psychiatric hospital because the former inmates, as residents of the TRs, were "quiet and living in their own world" compared with "some people who are worse than them". This may illustrate the acceptance of these individuals in the community; however, the statement "quiet and living in their own world" may indicate that the objectives of the mental health policies are not being achieved. Such statements illustrate the presence of a considerable degree of control and also reveal a symbolic separation from the inmates with no voice and who are "living in their own world" though they are neighbours. However, such representations can be used as a cognitive strategy that gives group members comfort: given their coexistence with difference, knowing that the former inmates are controlled and remain apart produces a sense of security.

Jodelet (2005) noted that social representations of inmates enabled distancing and separation strategies, which constitute a defence of group identity. These strategies suggest that the greatest risk to the community is not the dangerousness attributed to the former inmates but rather the removal of the difference that cognitively separates civilians from "insane individuals". Therefore, the community, “. . . seeking the best for its interests and its defence, created a social institution that allows it to integrate an exogenous group without its incorporation in the community" (p. 352). Similarly, the participants of the present study seem to integrate the former inmates of the psychiatric hospital into the neighbourhood; however, this integration is only partial, and the inmates are not incorporated as equals. This can be interpreted as a group defence mechanism in which ". . . each one thinks and acts as a representative and a defender of his/her group" (Jodelet, 2005, p. 253).

\section{The Conceptions of the Future of the Inmates without Family Ties}

Participants are aware that the housing complex is the destination for some of the former inmates of the psychiatric hospital and know about the presence of TRs in the neighbourhood. The TRs are understood as an extension of hospital treatment. Some participants emphasised that the TRs should be moved to places other than the housing complex because the former inmates would be trapped in the TRs and would not be able to sunbathe or engage in leisure activities. Thus, they needed a larger space with a garden and activities to do-"therapy while working", such as planting, harvesting and selling fruit. Thus, one of the participants described the ideal space: ranch-houses. In accordance with this idea, a study performed by Leão and Barros (2008) demonstrated that mental health patients require a space in an isolated area of the city, as suggested by a psychosocial services professional: "A larger space, a ground, a farm, where the individuals can have a space, where the individuals can get a sports court" (p. 101). Thus, this professional's vision is similar to the view expressed by the participants of the present study because it establishes that this population need a ranch. This idea requires discussion because it is not in keeping with the principles of deinstitutionalisation policies (Ministry of Health, 2000, 2011).

The social representations of hosting inmates on farms, agricultural places or away from the urban social context are similar to ideas that combine the therapeutic process with nature. In the nineteenth century, the construction of psychiatric hospitals corresponded to two main goals: the protection of society from insane individuals and the provision of therapy in which the spaces linked to the natural environment could be appropriated for the treatment of mental illness. Urban life was believed to stimulate men- 
tal disorders. Therefore, psychiatric hospitals were built in remote areas or included gardens, and some of them were actually characterised as colony-hospitals, such as the psychiatric hospital mentioned in the present study. In such institutions, unlike in the enclosed spaces of hospitals, nature was recognised as a potentially therapeutic place, as a type of exile from the city. Retreats were frequently prescribed. In addition, the initial architectural plans of the first psychiatric hospitals ensured that each ward overlooked a garden (Foucault, 2006; Venâncio, 2011).

Thus, the opinions expressed by the participants are in accordance with scientific knowledge that historically combined the treatment of insanity with separation from the urban context. Their ideas are also reflected in the history of the psychiatric hospital mentioned in the present study, which was characterised as a colony-hospital and was originally built in a remote area. In other words, the statements of the participants indicate the need for further reflection by the academic community, managers and professionals involved because they suggest that the former inmates, once located in their neighbourhood, should return to what would be a hospital-colony. Such attitudes make the social reintegration of the TR residents more difficult.

The representations that suggest the removal of the TRs are an obstacle to the social reintegration of former inmates of psychiatric hospitals. They indicate that when a psychiatric hospital is closed, people imagine the need for a place that has the same function, even referring to old concepts that resemble the first psychiatric hospitals in agricultural colonies, such as a ranchhouse. However, this idea of building a distant residence for former inmates is an attempt to defend the residents' group identity and emphasises the complexity of the deinstitutionalisation processes. Jodelet (2005) noted in her study that the families' social representations of the former inmates of psychiatric hospitals allowed the participants to create the distance needed to maintain the community's group identity. Their resistance to interaction was not associated with the dangerousness attributed to the inmates but to the risk that they would be fully incorporated into the group.

Therefore, the dangerousness historically attributed to insane individuals and emphasised by the closure of psychiatric hospitals is not the most important reason for the participants' use of cognitive and practical strategies of separation and removal. Instead, the risk of merging identities, the fear that the former inmates of the psychiatric hospital could be incorporated into the participants' group and in some way be confused with them, was paramount. Therefore, the distinction between the groups is necessary to maintain group identity. This separation could be achieved by keeping the psychiatric hospital in operation because it has historically been a reference for the housing complex and is part of the local landscape that constitutes the identity of the group living in the hospital's neighbourhood.

The need for the psychiatric hospital to continue operating or the construction of a ranch to accommodate the inmates of the psychiatric hospital may represent attempts to address the otherness represented by the inmates' insanity as they become the neighbours of and are incorporated into the environment of the participants, threatening the residents' group identity with the risk of fusion and that identity's subsequent disintegration. The insanity can then be diluted and incorporated into the group. Importantly, however, the need to preserve the group identity, as observed in the present study, promotes the exclusion of the former inmates of the psychiatric hospital, which is not in harmony with the principles of deinstitutionalisation (Basaglia, 1982; Ministry of Health, 2000, 2011; Rotelli et al., 2001) and is therefore a logic that needs to be contested.

\section{Final Considerations}

The present study discussed the social conceptions of a psychiatric hospital at a time when mental health policies advocate the closure of these institutions and the implementation of care for the inmates in local neighbourhoods. The ethnographic approach was appropriate for the 
proposed objectives, allowing the researchers to understand processes that were not evident in the interviews. For example, this method revealed the participants' effort to create a favourable image of the psychiatric hospital and the disappointment observed on their faces when they discussed its closure, as if their cowardice was being expressed: "I did not want to see it closed".

The data from the present study revealed a contradiction in the participants' statements. They discussed the possibility of coexistence with the TRs and described daily interactions with their residents, but they emphasised that the TRs should be moved from urban areas to other locations such as a ranch-house for the benefit of the former inmates, who could then participate in "the therapy of planting, harvesting and selling the fruit".

Some participants accepted the closure because the former inmates who live in the TRs are considered "non-dangerous". However, if the inmates living in the housing complex are not aggressive, why do they need to be separated, as illustrated by the "ranch-house"? According to the framework of social representations, the reason for this separation is the protection of group identity - the identity of the group that has to receive the inmates of the psychiatric hospital could be compromised.

In fact, the psychiatric hospital mentioned in the present study is a reference for the neighbourhood. It is part of the life of the participants and constitutes their identity. Accordingly, its closure would be adverse for the group image. Thus, the positive representation of the psychiatric hospital strengthens group identity, in addition to allowing the concrete separation of a real or symbolic threat by being a place and a social destination for inmates outside the housing complex.

The trend towards the separation of the TRs and their residents illustrates the difficulty of the deinstitutionalisation process and, more specifically, the social reintegration of former inmates of psychiatric hospitals, as indicated by the Ministry of Health (2011). This social rejection of the TRs needs to be problematised and reversed, which can be achieved by continued studies in this field and by increasing the awareness of society, especially in the neighbourhoods in which the TRs are located. There are positive attitudes that indicate the possibilities of social reintegration. However, the deinstitutionalisation policies still have little support from society and encounter numerous challenges, as demonstrated by the results of the present study.

In addition, data from studies on Italian deinstitutionalisation indicate that the dangerousness attributed to insane person is the main reason for continuing to operate lunatic asylums. However, based on the data of the current study, the association between inmates of the psychiatric hospital and aggressive behaviour and the perceived benefits of inmates' separation indicate that residents are primarily engaged in the defence of group identity - these ideas distance and separate this population from the participants' group of origin and reference. Thus, this process prevents the risk of mixture and the fusion of identities. Therefore, the need to establish a group identity disassociated of former inmates of the mental hospital was the main reason for the separation of the TRs, revealing a serious issue that must be resolved if the deinstitutionalisation movement is to succeed.

Though psychiatric hospitals are being closed, the belief in the need for their continued operation or for the construction of similar places remains. This belief is a mechanism for defending group identity but is also a significant obstacle to the deinstitutionalisation process and must be contested. Therefore, the possibility of this coexistence of former inmates of psychiatric hospitals must be discussed to ensure the coexistence of opposing rationalities because, despite the difference between groups, the exercise of rights, including the right to community life, must be equal.

\section{References}

Basaglia, F. (1982). Psiquiatria alternativa: Contra o pessimismo da razão, o otimismo da prática. Conferências no Brasil ( $3^{\text {rd }}$ ed., S. Soianesi \& M. C. Marcondes, Trans.). São Paulo, SP: Brasil Debates. 
Bonomo, M. (2010). Identidade social e representações sociais de rural e cidade em um contexto rural comunitário: Campo de antinomias (Doctoral dissertation, Programa de Pós-Graduação em Psicologia, Universidade Federal do Espírito Santo, Vitória, ES, Brazil).

Foucault, M. (2006). Microfisica do poder $\left(22^{\text {th }}\right.$ ed., R. Machado, Trans.). Rio de Janeiro, RJ: Graal.

Jodelet, D. (2005). Loucuras e representações sociais (L. Magalhães, Trans.). Petrópolis, RJ: Vozes.

Jovchelovitch, S. (2004). Psicologia social, saber, comunidade e cultura. Psicologia \& Sociedade, 16(2), 20-31.

Leão, A., \& Barros, S. (2008). As representações sociais dos profissionais de Saúde Mental acerca do modelo de atenção e as possibilidades de inclusão social. Saúde e Sociedade, 17(1), 95-106. doi:10.1590/S0104-12902008000100009

Leonardis, O., Mauri, D., \& Rotelli, F. (2001). Prevenir a prevenção. In F. Nicácio (Ed.), Desinstitucionalização ( $2^{\text {nd }}$ ed., pp. 65-78). São Paulo, SP: Hucitec.

Lima, M. F. de. (2005). "Nos caminhos da psicologia capixaba”: Notas para a história da psicologia, da psiquiatria e da saúde pública no Estado do Espírito Santo (Master's thesis, Programa de Pós-Graduação em Psicologia, Universidade Federal do Espírito Santo, Vitória, ES, Brazil).

Maciel, S. C., Barros, D. R., Camino, L. F., \& Melo, J. R. F. de. (2011). Representações sociais de familiares acerca da loucura e do hospital psiquiátrico. Temas em Psicologia, 19(1), 193-204.

Minayo, M. C. de S. (2004). O desafio do conhecimento: Pesquisa qualitativa em saúde ( $8^{\text {th }} \mathrm{ed}$.). São Paulo, SP: Hucitec.

Ministry of Health. (2000). Portaria 106 de 11 de fevereiro de 2000. Institui os Serviços Residenciais Terapêuticos no âmbito do SUS. Brasília, DF: Author. Retrieved from http://dtr2004.saude.gov.br/susdeaz/legislacao/arquivo/27_Portaria_106_de_11_02_2000.pdf

Ministry of Health. (2011). Saúde Mental no SUS: As novas fronteiras da Reforma Psiquiátrica. Relatório da gestão 2007-2010. Brasília, DF: Author. Retrieved from http://bvsms.saude.gov. br/bvs/publicacoes/saude_mental_fronteiras_reforma_psiquiatrica.pdf
Ministry of Health. (2012). Resolução $n^{\circ} 466$ de 12 de dezembro de 2012. Brasília, DF: Author. Retrieved from http://conselho.saude.gov.br/resolucoes/2012/Reso466.pdf

Moreira, M. I. B. (2007). Se esta casa fosse minha: Habitar e viver na cidade a partir de uma residência terapêtica (Doctoral dissertation, Programa de Pós-Graduação em Psicologia, Universidade Federal do Espírito Santo, Vitória, ES, Brazil).

Pacheco, J. G., Almeida, A. M. de O., \& Rodrigues, M. M. P. (2007). Representações sociais em movimento: A história de uma experiência. In $\mathrm{M}$. M. P. Rodrigues \& P. R. M. Menandro (Eds.), Lógicas metodológicas: Trajetos de pesquisa em psicologia (pp. 119-150). Vitória, ES: GM.

Rivas, C. Z., \& Inostroza, A. (2003). Identidad regional em um contexto de cambio - um estúdio em La Araucania, Chile. Psicología Política, 26, 73-92.

Rocha, A. L. C. da., \& Eckert, C. (2003). Etnografia de rua: Estudo de Antropologia urbana. Iluminuras, $4(7), 1-22$.

Rotelli, F., Leonardis, O., \& Mauri, D. (2001). Desinstitucionalização, uma outra via. In F. Nicácio (Ed.), Desinstitucionalização (2 ${ }^{\text {nd }}$ ed., pp. 17-59). São Paulo, SP: Hucitec.

Venâncio, A. T. A. (2011). Da colônia agrícola ao hospital colônia: Configurações para a assistência psiquiátrica no Brasil na primeira metade do século XX. História, Ciências, Saúde - Manguinhos, 18(1), 35-52. doi:10.1590/ S0104-59702011000500003
Recebido: $13 / 01 / 2015$

$1^{a}$ revisão: 16/07/2015

Aceite final: 12/08/2015 